\title{
Effect of Heat Stress on Yield Attributing Traits in Wheat (Triticum aestivum L.)
}

\author{
Ajit Tiwari, Shambhoo Prasad", Bandana Jaiswal, Kunvar Gyanendra, \\ Sonam Singh, and K.N. Singh \\ Department of Plant Molecular Biology and Genetic Engineering, Narendra Deva University of \\ Agriculture and Technology, Kumarganj, Faizabad-224229, (U.P.), India \\ *Corresponding author
}

\section{A B S T R A C T}

Keywords

Heat stress, MSI, SPAD value, Yield attributing traits, Wheat.

Article Info

Accepted:

19 October 2017

Available Online:

10 December 2017
An experiment was conducted with four wheat varieties i.e. Halna, HD2733, Raj3765 and K9006 to evaluate heat stress traits in wheat and consequently development of high yielding heat tolerant wheat varieties. Heat stress treatment was given by delayed sowing under field condition. Parameter related to growth and yield attributing traits were observed under control and heat stress regimes. Wheat varieties Halna and Raj3765 showed less reduction in plant height, tiller numbers, chlorophyll content (SPAD value), membrane stability index, grains/spike, test weight and grain yield under heat regimes comparatively HD2733 and K9006. Though HD2733 and K9006 showed high yield under control condition but its yield significantly reduced under heat stress at reproductive stage.

\section{Introduction}

Abiotic stress factors such as heat, cold, drought, salinity, and nutrient stress have a huge impact on world agriculture, and it has been suggested that they reduce average yields by $>50 \%$ for most major crop plants (Wang et al., 2003). Wheat is also no exception to this. Among abiotic stresses heat stress is one of important abiotic stress which wheat faces today. The average global temperature is reported to be increasing at a rate of $0.18^{\circ} \mathrm{C}$ every decade (Hansen et al., 2012; Annual Climate Summary, 2010). Though, heat stress affects the metabolic pathways at every stage of life of wheat finally leading to yield reduction, the effect of high temperature is particularly severe during grain filling; these losses may be up to $40 \%$ under severe stress (Wollenweber et al., 2003, Hays et al., 2007). Other effects of high temperatures are decreased grain weight, early senescence, shriveled grains, reduced starch accumulation, altered starch-lipid composition in grains, lower seed germination and loss of vigor (Balla et al., 2012)

Future climates will also be affected by greater variability in temperature and increased frequency of hot days (Pittock, 
2003). To adapt new crop varieties to the future climate, we need to understand how crops respond to elevated temperatures and how tolerance to heat can be improved (Halford, 2009).

\section{Materials and Methods}

A field experiment was conducted with four wheat varieties namely Halna, Raj 3765, HD 2733 and K 9006 for characterization of its physiological traits for heat stress tolerance in wheat. Wheat varieties were exposed to severe heat stress by 60 days delayed from normal sowing (15 November) so that temperature rise to $35-40^{\circ} \mathrm{C}$ at grain filling stage of wheat varieties could experience severe heat stress condition. General agronomic practices were done as per needs of the crop. Heat stress at dough stage of grain filling ranged between 37 and $39^{\circ} \mathrm{C}$. Plant height was recorded from ground surface of stem to the tip of stem at grain filling stage.

Leaf chlorophyll content was estimated by the chlorophyll meter (SPAD). Membrane Stability Index (MSI) was determined by recording the electrical conductivity of leaf leachate in double distilled water at $40^{\circ} \mathrm{C}$ and $100^{\circ} \mathrm{C}$ (Sadalla et al., 1980). Leaf sample $(0.1 \mathrm{~g})$ were cut into uniform small size and taken in test tubes containing $10 \mathrm{ml}$ of double distilled water in two sets for samples. One set was kept at $40^{\circ} \mathrm{C}$ for 30 minutes and another set at $100^{\circ} \mathrm{C}$ in boiling water bath for 15 minutes and their respective electrical conductivities as $\mathrm{C}_{1}$ and $\mathrm{C}_{2}$ were measured by conductivity meter [EC-TDS analysis ELICO (CM-183).

Membrane stability index (MSI) was recorded at reproductive stage of all four wheat varieties and calculated as percent injury. Membrane stability index (\% injury) was determined by the given formula,

\section{Results and Discussion}

The membrane stability index varied from variety to variety under control and stress condition (Fig. 1). The maximum membrane stability index values were recorded in Halna (69) and Raj 3765 (63) under control condition. The maximum reduction in membrane stability index was recorded in HD $2733(37.73 \%)$ while minimum in Halna (17.39\%).

Cell membrane stability, a measure of electrolyte diffusion resulting from heatinduced cell membrane leakage, has been used to screen and evaluate different wheat genotypes for thermal tolerance (Blum and Ebercon, 1981; Saadalla et al., 1990). Electrical conductivity has been used as an index of membrane stability to identify heattolerant genotypes in wheat (Blum and Ebercon, 1981) and for screening of heattolerant genotypes in different crops (Blum, 1988). When tissues are subjected to high temperature, electrical conductivity increases due to damage to the cell membrane and consequent solute leakage.

The chlorophyll content varied from variety to variety under control and stress condition (Fig. 2). The high SPAD values were recorded in K9006 (65) and HD2733 (63) under control condition. The heat stress reduced stay green duration of wheat varieties. The maximum reduction in chlorophyll content was recorded in HD 2733 $(26.33 \%)$ while minimum in Halna $(11.46 \%)$. Tolerant wheat varieties like Halna and Raj 3765 remained stay green for long duration at reproductive stage in comparison to heat sensitive HD2733 and K9006 wheat varieties.

Chlorophyll synthetic enzymes are heat sensitive and less functional during severe heat stress. It needs optimum temperature for proper function. When temperature increases 
the heat sensitive enzymes denatured and chlorophyll synthesis process decreases.

The formations of chlorophyll less affected in heat tolerance varieties as it specific proteins protect the integrity of heat sensitive enzymes and remain functional even under heat stress condition (Vierling, 1991; Zaharieva et al., 2001).

Wheat varieties showed the genetic diversity in plant height (Fig. 3). The maximum plant height was recorded in K9006 $(90.84 \mathrm{~cm})$ while minimum in HD 2733 (70.76) under control condition. Heat stress significantly reduced the plant height. The maximum \% reduction in plant height was recorded in HD $2733(30.75 \%)$ and K9006 (24.15\%) while low in Raj 3765 (11.87\%) and Halna $(17.25 \%)$ under the heat stress condition.

The reduction in plant height is due to fast phasic change and due to this, vegetative phase become short and reproductive come early (Vollen Weider and Gunthardt Goerg, 2005).

Fig.1 Effect of heat stress on MSI value of wheat varieties at reproductive stage

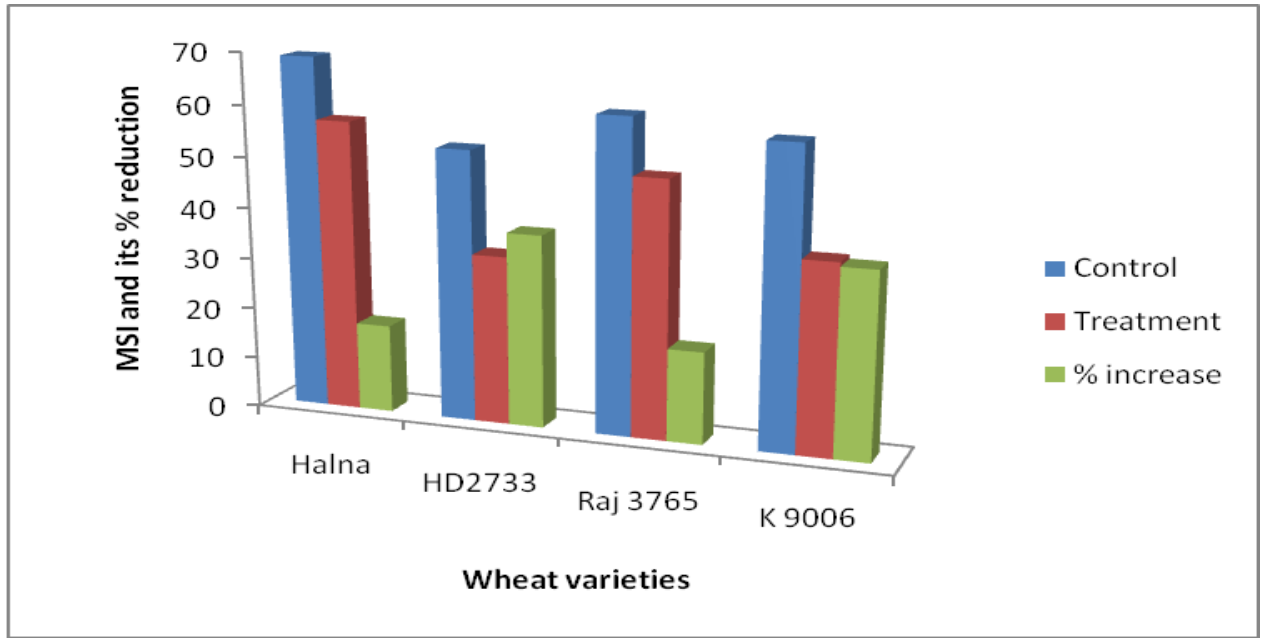

Fig.2 Effect of heat stress on SPAD value of wheat varieties at reproductive stage

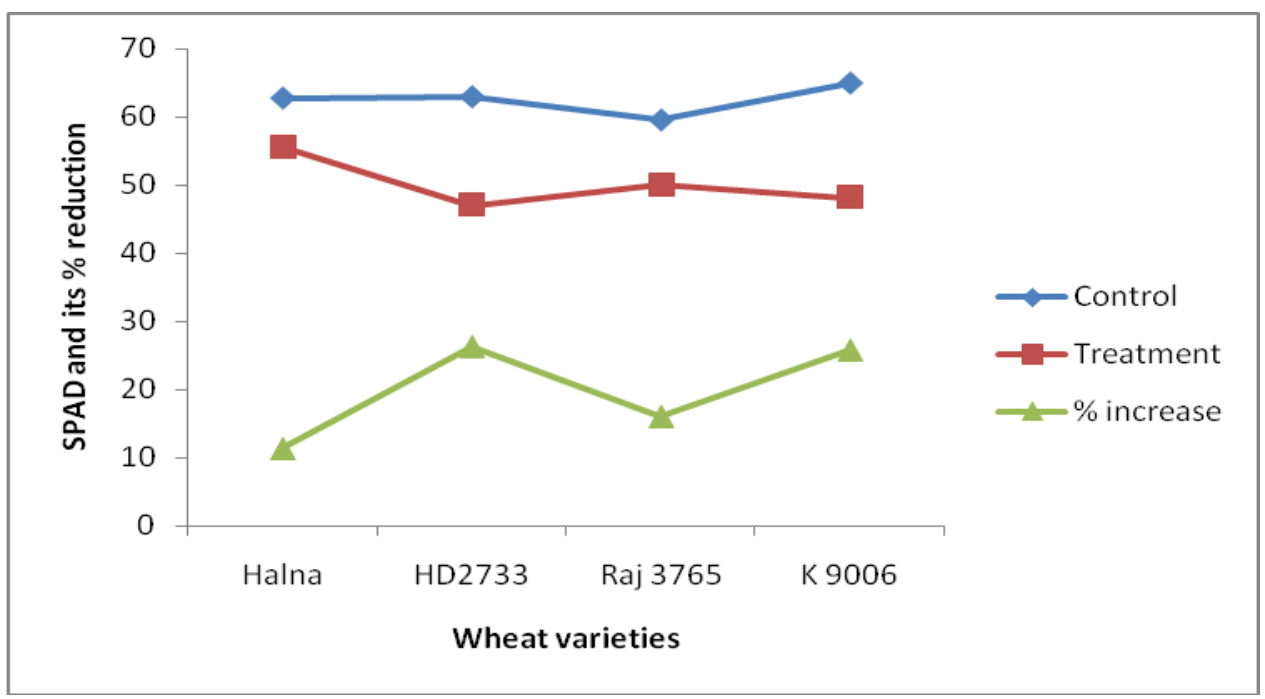


Fig.3 Effect of heat stress on plant height $(\mathrm{cm})$ of wheat varieties at reproductive stage

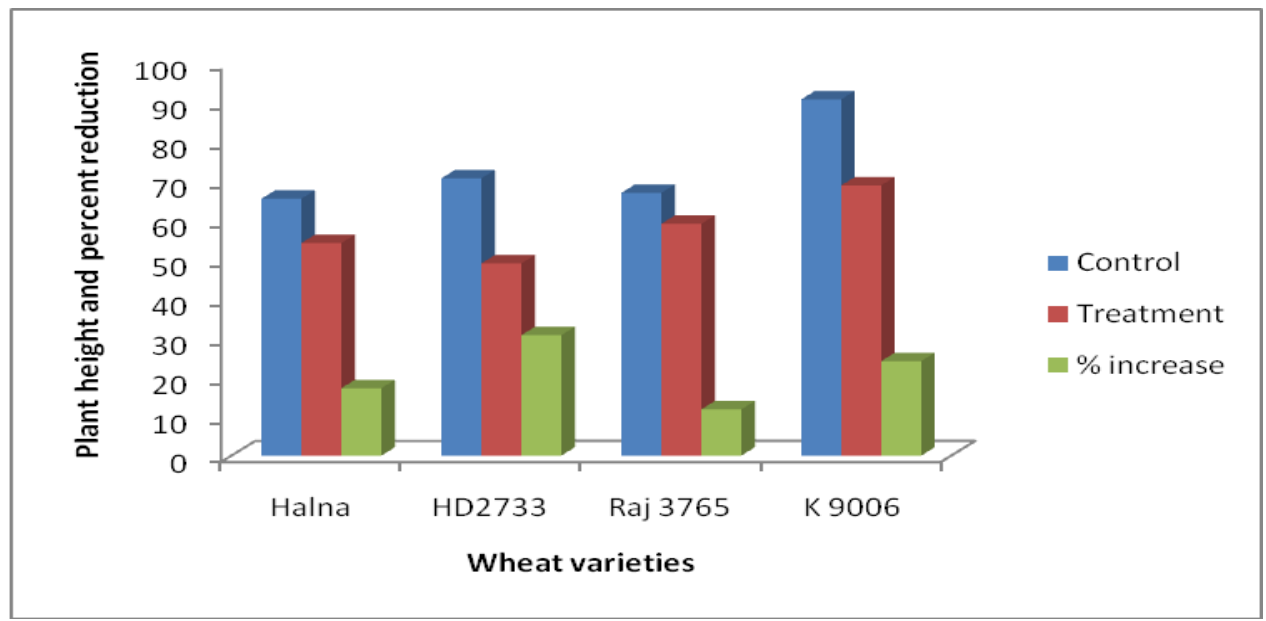

Fig.4 Effect of heat stress on tiller number of wheat varieties at reproductive stage

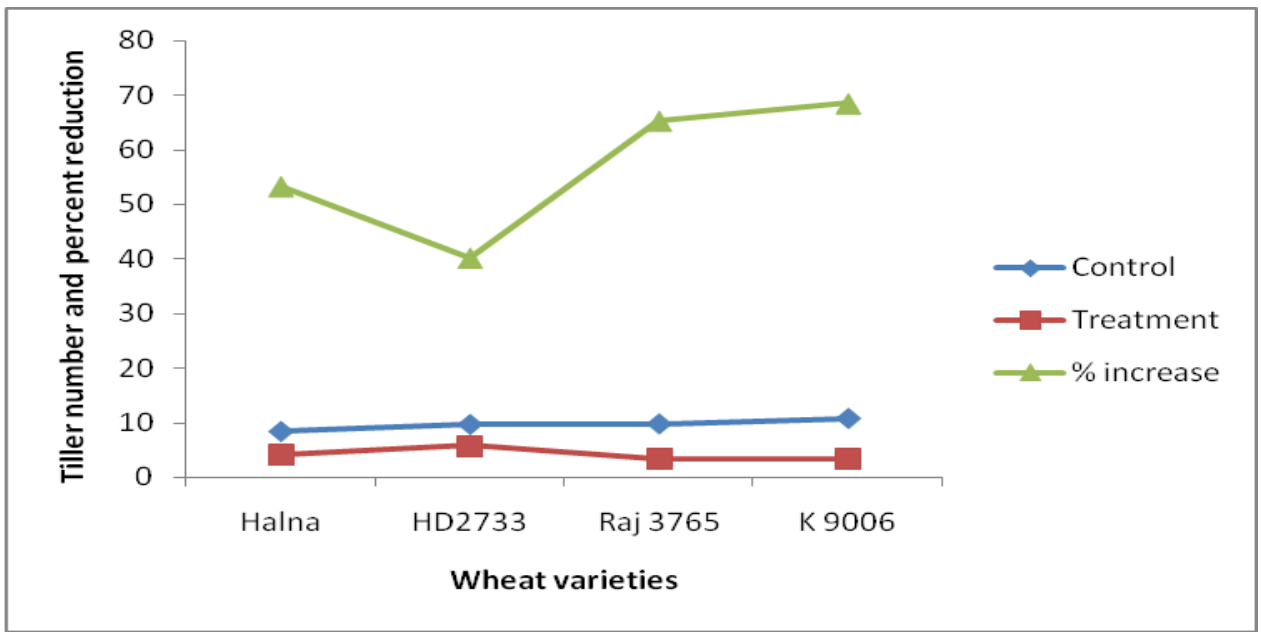

Fig.5 Effect of heat stress on test weight $(\mathrm{g})$ of wheat varieties

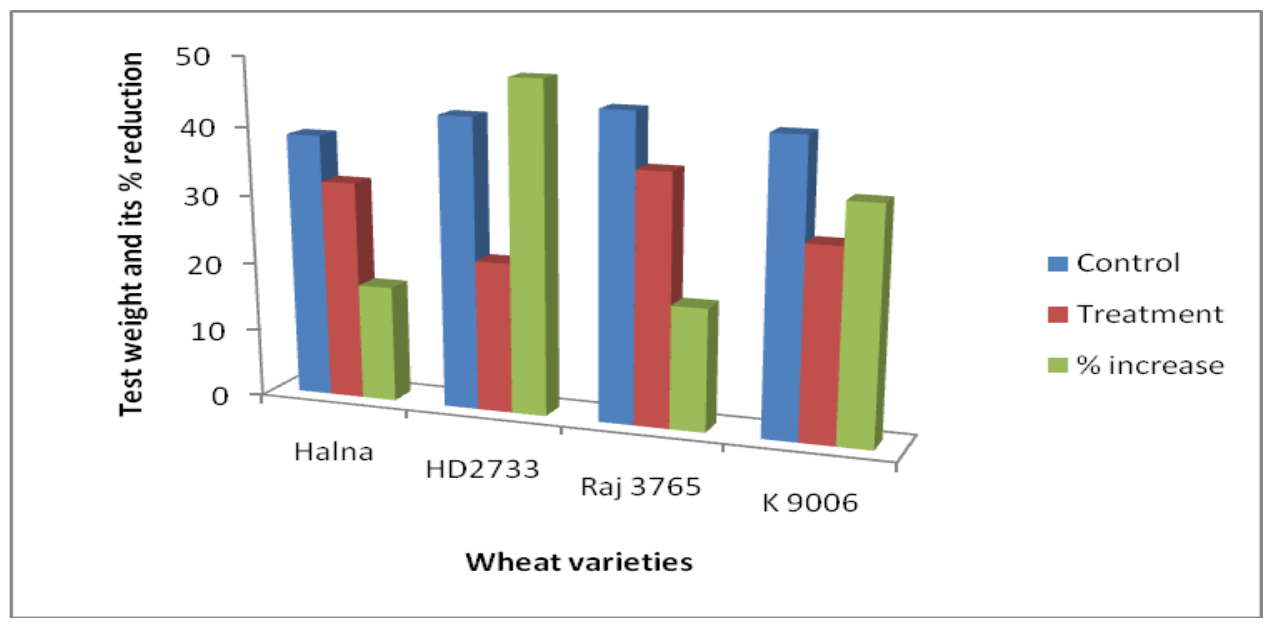


Fig.6 Effect of heat stress on grain yield $(\mathrm{cm})$ of wheat varieties

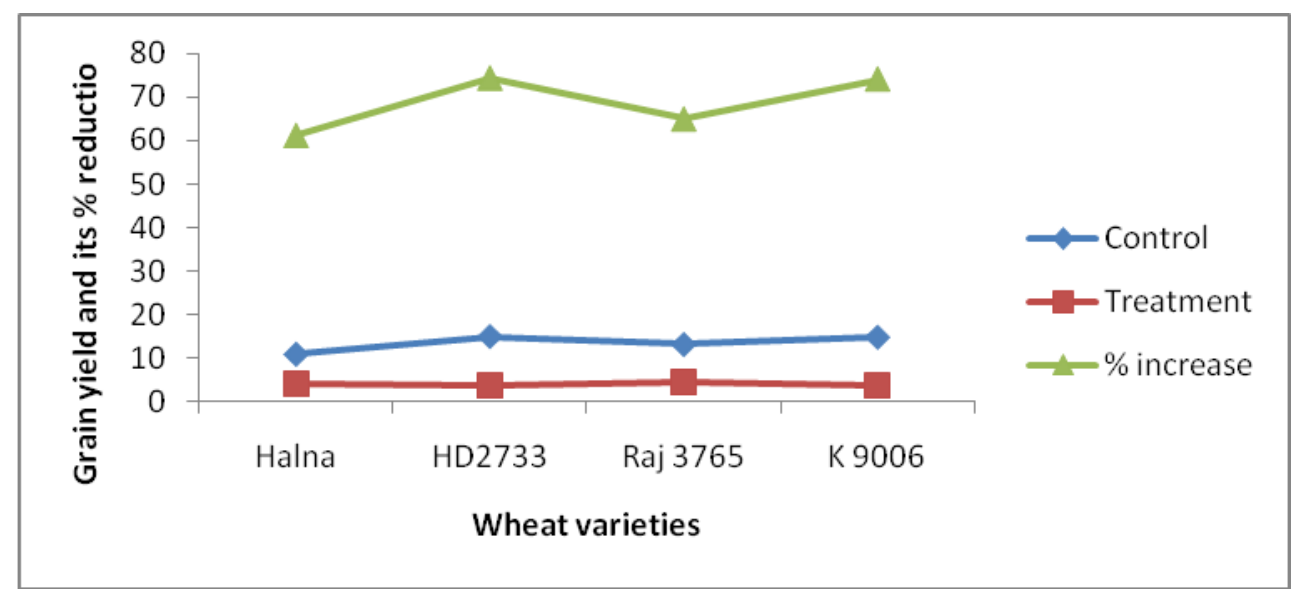

The maximum number of tiller per plant was recorded in K9006 (10.8\%) while minimum in Halna (8.4\%) under control condition (Fig. 4). Heat stress significantly reduced the number of tillers per plant. The high reduction in number of tillers per plant was recorded in K 9006 (68.52\%) and Halna (65.31\%) while low in HD $2733(40 \%)$ and Halna (53\%) under the heat stress condition.

Heat stress during early growth stages adversely affects formation of first node i.e. responsible for tiller numbers and resultantly, it also affects the number of spikelet per plant, resulting in reduced sink capacity and future source capability of the plants (Sharma, et al., 2001).

The test weight varied among wheat varieties in control and heat stress condition (Fig. 5). Raj 3765 (44.5 g) showed maximum test weight followed by HD2733 (42.5 g), K 9006 (42 g) and Halna (38.6 g) in control condition. Halna (17.14 \%) and Raj 3765 (17.98\%) showed minimum $\%$ reduction in test weight while HD 2733 (48.28 \%) and K 9006 (34.12 $\%)$ under heat stress condition.

Late sowing markedly reduced 1000 grain and grain yield per plant by 8.7 and $22 \%$ respectively (Kheiralland and Sherif,
1992).Increasing mean daily air temperature caused decrease of $2.8 \mathrm{mg}$ per degree centigrade (Weigand and Cuellar, 1981).

The grain yield varied among wheat varieties in normal and heat stress condition (Fig. 6). HD2733 showed maximum grain yield (15.07 g) followed by K 9006 (14.98 g) Raj 3765 $(13.38 \mathrm{~g})$ and minimum in Halna (10.9 g) in control condition. Under heat stress condition, less reduction was recorded in Halna and Raj 3765 comparatively HD 2733, HD 2733 and K 9006.

According to (Ruwali and Bhawsar, 1998) grain yield reduced by 5 to $10 \%$ per $1^{\mathrm{oC}}$ increase in maximum/ minimum temperature due to reduction in biomass, productive tillers, flowering period, grain number and 1000 grain weight. Heat stress decreases the yield due to affecting growth and development processes, lowering the yield component potential and affecting the activity of key enzymes that contribute a lot during grain filling and development (Wahid et al., 2007).

Heat stress at reproductive stage is major problem in North-Western part of India. It significantly reduced the growth, number of tillers per plant, chlorophyll content, and yield 
of wheat varieties. High percent reduction in these parameters was recorded in HD 2733 and K9006 in comparison to Halna and Raj 3765. The wheat varieties that had high membrane stability stay green duration showed less reduction in growth and yield. These parameters can be taken as screening criteria for selection of heat tolerance wheat varieties.

\section{References}

Acevedo, E, Nachit, M and Ferrara, GO 1991. Effects of heat stress on wheat and possible selection tools for use in breeding for tolerant. D.A. Saunders, ed. Wheat for the nontraditional warmer areas. Mexico, D.F: CIMMYT. Pp. 401-421,

Al Khatib, K. and Paulson 1987. Mode high temperature injury to wheat during grain development. Plant Physiol., 61: 363-368.

Al-Khatib, K. and Paulsen, G.M. 1984. Mode of high temperature injury to wheat during grain development. Plant Physiol., 61: 363368.

Al-Khatib, K. and Paulsen, G.M. 1999. High temperature effects on photosynthetic processes in template and tropical cereals. Crop Sci., 39:119-125.

Amandeep, K., Sohu, V.S. and Mavi, G.S. 2007. Genotypic variation for physiological traits associated with heat tolerance in bread wheat (Triticum aestivum L.). Crop. Improvement, 34(2): 117-123.

Annual Climate Summary 2010. Issued by National Climate Centre Office of the Additional Director General of Meteorology (Research) India Meteorological Department, Pune-411 005.

Balla, K, Karsai, I, Bencze, S and Veisz, O 2012. Germination ability and seedling vigour in the progeny of heat-stressed wheat plants. J.Acta.Agron. Hung. 60(4): 299-308.

Blum, A. 1988. Plant breeding for stress environments. CRC Press, Inc., Boca Raton, Florida, pp. 223.

Blum, A. and Ebercon, A. 1981. Cell membrane stability as a measure of drought and heat tolerance in wheat. Crop Science 21: 43-47.

Ferrera, O.G., Rajaram, S. and Mosaad, M.G.
1993. Breeding strategies for improving wheat in heat stressed environments. Proc. Int. Conf. Wad Medani, Sudan and Dinajpur, Bangladesh. Pp. 24-32.

Halford, NG 2009. New insights on the effects of heat stress on crops. J. Exper. Bot. 60: 4215-4216.

Hansen, J., Sato, M.K. and Ruedy, R. 2012. Perception of climate change. Proc. Natl. Acad. Sci. 109:14726-14727.

Harding, S.A., Guikema, G.A. and Paulsen, G.M. 1990. Photosynthetic decline from high temperature stress during maturation of wheat. II Interaction with source and sink processes. Plant Physiol., 92: 654- 658.

Hays, D, Mason, E, Hwa, Do J, Menz, M and Reynolds, M 2007. Expression quantitative trait loci mapping heat tolerance during reproductive development in wheat ( $T$. aestivum). In: Buck HT, Nisi JE, Salomo'n $\mathrm{N}$ (eds.), Wheat production in stressed environments. Springer, Amsterdam, pp 373-382.

Herzog, H. 1982. Relation of source and sink during the grain filling period in wheat and some aspects of its regulation. Physio Plant 56:155-166

Kheiralland, K.A. and Sherif, T.H. 1992. Inheritance of earliness and yield in wheat under heat stress. Aust. J. Agric. Sci., 23: 105-126.

Kohli, MM, Mann, C and Rajaram, S 1991. Global status and recent progress in breeding wheat for the warmer areas. DA Saunders, ed. Wheat for the nontraditional warmer areas. Mexico, D.F: CIMMYT, 225241.

Kuroyanagi, T. and Paulsen, G.M. 1985. Mode of high temperature injury to wheat. II. Comparison of wheat and rice with and without inflorescences. Physio Plant 65:203-208

Murata, Y. and Lyama, J. 1963. Studies on photosynthesis of forage crops II, Influence of air temperature upon the photosynthesis of forage and grain crops. Proc Crop Sci Society of Japan, 31:315- 321

Rane, J. and Nagarajan, S. 2004. High temperature index-for field evaluation of heat tolerance in wheat varieties. Agricultural Systems, 79(2):243-255. 
Ruwali, K.J. and Bhawsar, R.C. (1998) Effect of high temperature on grain development of wheat under late shown irrigated condition. In wheat research needs beyond 2000 AD. Proc. Int. Conf. Karnal. India. pp. 68-69.

Saadalla, M.M., Quick, J.S. and Shanahan, J.F. 1990. Heat tolerance in winter wheat: II. Membrane thermostability and field performance. Crop Science 30:1248-1251.

Sairam, R.K., Srivastava, G.C., Saxena, D.C. 2000. Increased antioxidant activity under elevated temperature: A mechanism of heat stress tolerance in wheat genotypes. Biol. Plant. 43:245-251.

Sharma, S.; Shahu, V.S. and Dhindsa, G.S. 2001. Genetic variation for foliar traits in wheat varieties exposed to different thermal regimes. In: Kharwal; M.C. and Mehra, R.B. (Eds) Hundred years of PostMendelian Genetics and Plant BreedingRetrospect and prospects, Sym. Proc., p. 165, New Delhi.

Singh, J.P., Shambhoo P., Singh K.N., and Randhir, S. 2007. Screening of heat tolerant wheat varieties by membrane thermostability index in relation to yield and yield attributing traits. Int. J. Plant Sci. Muzzaffarmagar, 2(2): 159-165.

Slovacek, R.E. and Hind, G., 1981. Correlation between the photosynthesis and the transthylakoid proton gradient. Biochem Biophys Acta., 35: 393-404.

Spiertz, JHJ., 1974. Grain growth and distribution of dry metter in the wheat plant as influence by temperature, light energy and seed sizentry. Neth. J Agri Sci., 22: 207-220.

Takai, T, Fukuta, Y., Shiraiwa, T. 2005. Timerelated mapping of quantitative trait loci controlling grain-filling in rice (Oryza sativa L.). J Exp Bot, 56: 2107-2118.

Vierling, E. 1991. The role of heat shock proteins in plants. Ann. Rev. Plant Physiol. and Plant Mol. Biol., 42: 579-620.

Vollen Weider, P. and M. S. Gunthardt-Goerg 2005. Diagnosis of abiotic and biotic stress factors using the visible symptoms in foliage. Environ. Pollut., 137: 455-465.

Wahid A, Gelani S, Ashraf M, Foolad MR 2007. Heat tolerance in plants: An overview. Environmental and Experimental Botany, 61: 199-223

Wang, W.X., Vinocur, B. and Altman, A., 2003. Plant responses to drought, salinity and extreme temperatures: towards genetic engineering for stress tolerance. Planta, 218, 1-14.

Wiegand CL, Cuellar JA 1981. Duration of grain filling and kernal weight as affected by temperature. Crop Sci., 21:95-101.

Wiegand, C.L. and Cuellar, J.A. 1981. Duration of grain filling and kernel weight of wheat as affected by temperature. Crop Sci., 21: 95101.

Wollenweber, B, Porter, JR and Schellberg, J 2003. Lack of interaction between extreme high-temperature events at vegetative and reproductive growth stages in wheat. $J$. Agron. Crop Sci., 189:142-150.

Yemm, E. W. and E. J. Willis 1954. The estimation of carbohydrate in plant extract by anthrone. J. Biochem., 57: 508-514.

Zaharieva, M., E. Gaulin, M. Havraux, E. Eacevedo and P. Monneveux 2001. Drought and heat response in the wild wheat relative Aegilopes Roth: Potential interest wheat. Crop Sci., 41: 1321-1329.

\section{How to cite this article:}

Ajit Tiwari, Shambhoo Prasad, Bandana Jaiswal, Kunvar Gyanendra, Sonam Singh and Singh, K.N. 2017. Effect of Heat Stress on Yield Attributing Traits in Wheat (Triticum aestivum L.). Int.J.Curr.Microbiol.App.Sci. 6(12): 2738-2744. doi: https://doi.org/10.20546/ijcmas.2017.612.317 